\title{
SCURTĂ INCURSIUNE ÎN LUMEA LITERARĂ A SCRIITORILOR CONTEMPORANI ROMÂNI DE EXPRESIE SPANIOLĂ
}

\author{
A BRIEF INCURSION INTO THE LITERARY WORLD \\ OF CONTEMPORARY ROMANIAN WRITERS \\ IN SPANISH
}

\author{
Ioana CECOVNIUC1 \\ https://doi.org/10.52744/9786062613242.16
}

\begin{abstract}
Rezumat: Prezenta lucrare are ca principal scop o scurtă trecere în revistă prin lirica a trei scriitori români contemporani ce-şi desfăşoară activitatea literară într-un spațiu geografic diferit de cel al țării de origine. Conceptul de „literatură ectopică” propus de către Tomás Albaladejo Mayordomo (o literatură a „dislocării lingvistice şi culturale”, 2011) stă la baza receptării condițiilor şi factorilor ce explică această formă de expresie artistică. Corespunzătoare acesteia se scot în evidență date biografice semnificative şi teme principale abordate.
\end{abstract}

Cuvinte cheie: Literatură interculturală; Literatură ectopică; Autori români; Limba spaniolă

\begin{abstract}
The aim of this paper is to briefly review the work of three contemporary Romanian poets from an ectopic point of view. Consequently, the starting point will be from Tomás Albaladejo Mayordomo's definition of "ectopic literature" (2011), seen as the literature that is produced by an author who changes his usual topos (physical, socio-cultural and linguistic background) for an initially odd or peculiar one. Distinctive features of "ectopic literature" as well as significant factors - such as autobiographical data and main themes - are earmarked to be applied to the work for subsequent analysis.
\end{abstract}

Keywords: Intercultural Literature; Ectopic Literature; Romanian Voices; Spanish Language

\section{Introducere}

Prin literatură, concept asimilat ca un întreg al producțiilor scrise reflectînd un loc, o epocă, un gen sau o tendință, se pun temelii ce mişcă şi clădesc atitudini şi înţelegeri ale universului uman. Teme, motive, conținuturi, caractere, cuvinte şi forme compun un nelimitat rezervor de

${ }^{1}$ Lector univ. dr. al Facultății de Limbi şi Literaturi Străine, Universitatea Creştină Dimitrie Cantemir, ioana.cecovniuc@ucdc.ro 
interferențe şi influențe lingvistice şi culturale. Astfel, grație marilor opere şi voci naționale se pot depăşi frontiere temporale şi geografice către creaţii literare din alte culturi, scrise în alte limbi şi, prin urmare, către o îmbogăţire emoțională şi cognitivă în ceea ce priveşte literatura şi ființa umană. Trăsătură majoră a literaturii, interculturalitatea implică o călătorie spirituală în jurul lumii a celor ce citesc şi scriu.

În secolele XX şi XXI, această călătorie este uşor înlesnită de mijloacele moderne de transport pentru a fi şi de natură fizică. Despărțindu-se, din motive sociale şi economice, de pământurile natale pentru a se stabili în alte contexte geografice mulți dintre cei care ajung să scrie şi să creeze literatură experimentează un transfer personal, atât cultural, cât şi lingvistic într-un spațiu diferit de cel propriu, de origine, până într-atât încît noul spațiu de viață devine unul obişnuit şi familiar. Se construieşte astfel ceea ce profesorul de Teorie a Literaturii şi de Literatură Comparată Tomás Albaladejo Mayordomo (Universitatea Autonomă din Madrid) denumeşte "literatură ectopică" (2011, 143):

«Literatura ectópica» es una expresión que puede ser utilizada para denominar la literatura que ha sido escrita por autores que se han desplazado de su lugar de origen a otro lugar, implicando ese desplazamiento en muchos casos inmersión en una realidad lingüística distinta de la de origen e incluso cambio de lengua. Es la literatura que es producida fuera del lugar propio, fuera del espacio o territorio, en sentido geográfico y también en sentido cultural, en el que ha nacido o se ha formado el sujeto productor de dicha literatura. Es la literatura que está fuera del que sería su topos propio y se sitúa en otro topos, que también es lugar, espacio, pero distinto del previsible. Es la literatura que, a falta de su territorio habitual, encuentra otro territorio; es ectópica en relación con el topos primero, el habitual. El título de las memorias de Edward Said, Out of Place (Said, 1999), puede ser tomado como patrón para esta literatura, la cual, sin embargo, es más antigua, habiendo producido sus primeras obras en diversos momentos históricos; es, por ejemplo, en la obra de José Blanco White, emigrado de España a Inglaterra en el siglo XIX. Los seres humanos han migrado históricamente y han creado obras literarias en nuevos espacios, distintos de sus lugares de origen (Castaño, 2004, Albaladejo, 2008). Así, podemos hablar de "autor ectópico" y de "obra ectópica" como expresiones relacionadas con la literatura ectópica.

În istoria literaturii universale sînt extrem de numeroase exemplele de autori ce au scris şi scriu în arii geografice diferite față de cele în care s-au născut. În directă legătură cu această realitate socio-culturală, se consideră ca fiind extrem de important de observat condițiile, circumstanțele şi particularitățile fiecărui caz de literatură ectopică. În acest mod, se pot identifica aspecte ale «dislocării lingvistice şi culturale» proprii fiecărei situații în parte. Două exemple în acest sens pot fi poetul spaniol Emilio Prados (1899-1962), un «autor ectopic» în limba sa 
maternă într-o țară gazdă unde se vorbeşte aceeaşi limbă (în Mexic între 1939-1962), în timp ce romancierul britanic Kazuo Ishiguro, născut în Japonia în 1954, este un «autor ectopic» în limba țării gazdă (în Regatul Unit din 1960). Ca atare, au fost evidențiați diverşi parametri prin care se disting diferitele forme de literatură ectopică (Albaladejo, 2011:143-144): relația socio-politică şi culturală dintre țara de origine şi țara gazdă, distanța fizică şi de asemenea diferențele socio-culturale dintre țara de origine şi cea de adopție, relația dintre limba maternă şi limba adoptată, schimbarea naționalității/dubla cetățenie, vârsta «dislocării lingvistice şi culturale», conexiunea dintre emitent şi receptor.

În lumina celor expuse, în prezenta lucrare se remarcă trei destine româneşti ce au ales limba spaniolă - o limbă «dobândită» - ca mijloc de viaţă şi expresie artistică. Ioana Gruia, Mihai Gane şi Alina Diaconu născuți în spațiul geografic, lingvistic şi cultural românesc regăsesc în limba spaniolă un al doilea cămin, un teritoriu nou de vitalitate şi bogăție literară.

\section{Ioana Gruia}

Printre vocile artistic-literare ce trăiesc şi scriu în afara granițelor României se aude şi se ascultă Ioana Gruia (1978, Bucureşti), „această poetă fină, senină, elegantă, de origine română, stabilită în Granada”. Aprecierea profesorului şi scriitorului spaniol Fernando Aramburu vine odată cu lectura volumului de poezii Carrusel (Carusel), volum recunoscut în 2015 în spațiul iberic cu prestigiosul Premiu de Poezie Emilio Alarcos. În Spania din 1997, Ioana Gruia devine cercetătoare şi profesoară de teorie literară şi literatură comparată la Universitatea din Granada. Îşi dezvoltă şi armonizează cariera academică scriind şi publicând în limba spaniolă poezii, romane şi eseuri. Cu Otoño sin cuerpo (Toamnă fără trup) este, în 2002, finalistă a Premiului de Poezie Federico García Lorca ca mai tîrziu, în 2011, să fie distinsă pentru textul poematic El sol en la fruta (Soarele în fruct) cu Premiul Andalucía Tînără. Ca romancieră, atrage atenția în $2013 \mathrm{cu}$ titlul La vendedora de tiempo (Vînzătoarea de timp), o carte pentru care primeşte recenzii elogioase din partea unor personalități renumite din sfera literaturii în limba spaniolă cum sunt Luis García Montero sau Fernando Iwasaki. În 2016, El expediente Albertina (Dosarul Albertina) este primit şi aclamat cu Premiul Internațional Tiflos pentru roman. Sunt de remarcat, de asemenea, propunerile eseistice ale Ioanei Gruia - în 2009, Eliot y la escritura del tiempo en la poesía española contemporánea (Despre Eliot şi timp în poezia spaniolă contemporană) şi în 2015 La cicatriz en la literatura europea contemporánea (Cicatricea în literatura europeană contemporană) - eseuri în care autoarea identifică teme şi expune analize 
profunde şi complexe despre construcții literare în lumina unui context filozofic şi socio-politic.

Inserția totală în lumea limbii şi literaturii spaniole o face pe Ioana Gruia să îşi plăsmuiască un nou univers prin care îşi exteriorizează sensibilitatea, forța de sugestie şi pasiunea. Încadrându-se în linia autorilor ce aleg limba de adopție ca modalitate introspectivă de expresie, Ioana Gruia dezvăluie o selecţie tematică ce caracterizează, în general, literatura ectopică: căutarea identității, conştiința alterităţii, dorul şi amintirile, experiențele şi emoțiile trăite departe de casă (îndoieli şi temeri, melancolii şi speranțe). Temă majoră, identitatea este salvată prin remodelare, dar şi prin nevoia constantă de recunoaştere a unui nume de botez românesc (Ioana) în ciuda trecerii timpului departe de rădăcini şi deci a unei inevitabile reinventări a memoriei:

\begin{tabular}{|c|c|}
\hline $\begin{array}{c}\text { SI TÚ ME LLAMAS IOANA } \\
\text { (El sol en la fructa) }\end{array}$ & $\begin{array}{c}\text { DACA TU MĂ CHEMI IOANA } \\
\text { (Soarele în fruct) }\end{array}$ \\
\hline $\begin{array}{c}\text { Si tú me llamas Ioana } \\
\text { con la misma voz que dice amor mío, } \\
\text { soy bella y luminosa, } \\
\text { reconozco mi cuerpo, } \\
\text { la casa, los objetos, } \\
\text { entre palabra y palabra. } \\
\text { Pero si dejas de llamarme Ioana } \\
\text { con la misma voz que dice amor mío } \\
\text { mi cuerpo no sabrá quién es Ioana, } \\
\text { me quedaré sin casa, sin objetos, } \\
\text { sin belleza, sin luz y sin palabras. }\end{array}$ & $\begin{array}{c}\text { Dacă tu mă chemi Ioana } \\
\text { cu aceeaşi voce care spune iubirea mea, } \\
\text { sunt atrăgătoare şi luminoasă, } \\
\text { îmi recunosc trupul, } \\
\text { casa, obiectele, } \\
\text { intre cuvânt şi cuvânt. } \\
\text { Dar dacă nu mă mai chemi Ioana } \\
\text { cu aceeaşi voce care spune iubirea mea } \\
\text { trupul nu va mai şti cine e Ioana, } \\
\text { voi rămâne fără casă, fără obiecte, } \\
\text { fără frumusețe, lumină sau cuvinte. }\end{array}$ \\
\hline
\end{tabular}

LA EXTRAÑ $A$

(El sol en la fructa)

\section{STRĂINA}

(Soarele în fruct)
Llamo a la puerta de la extraña que se asoma, dentro de mí, a la ventana de un pasadizo. Pero no me responde.

Y me pregunto qué estancias une el pasadizo. Y a qué puerta estoy llamando.
Bat la uşa străinei care apare, înăuntrul meu, la fereastra unui coridor. Dar nu-mi răspunde.

Şi mă întreb ce camere unesc coridorul. Şi la ce uşă bat.

Mostră de accente şi nuanțe, lirica plină de nostalgie ("urmele unui animal pe zăpadă”) din volumul Carrusel (Carusel) arată, de aemenea, această căutare deplină a sinelui printr-un limbaj plin de idei şi imagini, punți între spații şi timp aşa cum o mărturiseşte însăşi poeta²:

${ }^{2} \mathrm{http}: / /$ www.ioanagruia.com/carrusel/ 
El vértigo del carrusel enseña la ilusión y el desamparo. Conversar con la propia infancia implica descubrir las cicatrices que nos componen. Los temas que aparecen en Carrusel son la infancia en tanto que etapa incorporada a nuestra identidad de adultos, una identidad oscilante entre la celebración y el fracaso, la complejidad de lo femenino, la maternidad, el amor como salvación y también como fractura, el erotismo, la crueldad del mundo contemporáneo y los múltiples otros que habitan nuestra subjetividad
Vîrtejul caruselului ne învață iluzia şi abandonul. A conversa cu propria copilărie implică a descoperi cicatricile care ne compun. Temele care apar în Carusel sunt copilăria ca etapă încorporată identității noastre de adulți, o identitate care oscilează între vitalism şi conştiința eşecului, complexitatea femininului, maternitatea, iubirea ca salvare, dar şi ca fractură, erotismul, cruzimea lumii contemporane şi numeroşii ceilalţi care trăiesc în interiorul nostru.

Alegerea limbii materne sau a celei «dobândite» drept instrument de comunicare îi indică în acelaşi timp şi pe cititorii ce alcătuiesc un public atent şi empatic. Din acest punct de vedere, în procesul constant de cunoaştere şi autocunoaştere, Ioana Gruia caută un echilibru şi îşi traduce textele din spaniolă în română, aşa cum se ilustrează în continuare cu cîteva dintre poeziile sale din Carrusel (Carusel):

CARRUSEL

En los años noventa construyeron el carrusel dorado en Bucarest. La ciudad aprendía a divertirse, tímida y desconfiada todavía.

Yo también aprendí en el tiovivo la embriaguez de un vértigo extranjero. Llegaba a ritmo de lambada y Jackson, de botella de Coca-Cola y Pepsi.

Un mundo chispeante comenzaba y había que bailarlo muy deprisa. Subir al cielo rápido, mirarlo en la tristeza gris de los tejados.

No podía parar de dar más vueltas. Como si descubriera algún secreto, algún oculto don en la subida, para repetición de la alegría.

La ciudad se veía como siempre, en tonos apagados y brutales.

Inmuebles feos, sombras con abrigos, todo seguía igual, pero lejano.

\section{CARUSEL}

În anii nouăzeci au construit caruselul auriu în Bucureşti. Oraşul învăța să se distreze, încă timid şi neîncrezător.

Am învățat şi eu în carusel beția unei amețeli străine. Sosea pe ritmuri de lambada şi Jackson, de sticle de coca-cola şi pepsi.

O lume sclipitoare începea şi trebuia să o dansăm în grabă. Să ne urcăm rapid în cer şi să-l privim în tristețea gri a acoperişurilor.

Nu mă puteam opri din învârteală.

Ca şi cum aş fi descoperit un secret, un dar ascuns în urcare, o pură repetiție a fericirii.

Oraşul se vedea ca întotdeauna, în tonuri stinse şi brutale.

Clădiri urâte, umbre cu paltoane, totul era la fel, doar că departe. 
Aprendí así las formas de espejismo como niñas que no quieren bajar, saber de la embriaguez el desamparo.

Hoy no va nadie al carrusel, ya viejo, pero yo me imagino aún sus giros. Y mis instantes de alegría intensa relumbran como el carrusel dorado que la vida mantiene agazapadas,

Am învățat aşa formele mirajului, pe care viața le păstrează ghemuite, ca fetițe care nu vor să coboare, să cunoască abandonul amețelii.

Azi nu mai merge nimeni la bătrânul carusel,

dar eu mi-aduc încă aminte de rotirile sale.

Şi momentele mele de fericire intensă strălucesc ca şi caruselul aurit.

\section{FUERA DE CAMPO \\ (Bucarest, 1972)}

Aquí miras absorta a alguien o algo

que está fuera de campo.

Eres joven en esta vieja foto, madre, pero tienes

la sonrisa cansada del fracaso.

Vives

en un país cruel e incomprensible.

El mundo está, lo sabes, en otra parte, en un fuera de campo imaginario, porque cualquier encuadre será siempre igual de desolado.

Has aprendido ya que aquí no existe ningún fuera de campo

\section{PLAN ÎN AFARA Ĉ̂MPULUI (Bucureşti, 1972)}

Aici priveşti îngândurată pe cineva sau ceva

în afara câmpului.

Eşti tânără în aceasă veche fotografie, mamă, dar ai zâmbetul obosit al eşecului.

\section{Trăieşti}

într-o țară crudă şi de neînțeles.

Lumea se află, ştii, în altă parte, pentru că orice cadraj va fi mereu la fel de dezolant. într-un plan imaginar în afara câmpului,

Ai învățat deja că aici nu există nici un plan în afara câmpului.

\section{SUMMERTIME EN EL PONT DES ARTS}

Cuando sueño que voy a la deriva, el saxo me rescata allá en el Pont des Arts.

Igual que esos candados de amor que hay en el puente,

tiran de mí los miedos hacia abajo.

Alguien toca despacio Summertime, lo oigo desde el fondo de mi sueño.

Es verano otra vez y tú caminas a mi encuentro en el Pont des Arts.
SUMMERTIME PE PONTS DES ARTS

Când mă visez plutind în derivă, saxofonul mă salvează pe Pont des Arts.

Ca lacătele de iubire de pe pod trag fricile de mine în jos.

Cineva cântă încet Summertime, îl aud din adâncul visului.

E vară din nou şi tu vii înspre mine pe Pont des Arts.

Şerpuită şi fierbinte, ca un aer de jarz, 
Enroscado y caliente, como un aire de jazz,

el deseo me asalta,

me arquea por encima de los miedos.

Nadie escapa a sus sueños, tampoco a sus canciones. dorința mă cuprinde,

mă arcuieşte pe deasupra fricii.

Nimeni nu scapă de visele sale, nici de propriile cîntece.

\section{LA CASA POEMA}

Me gustaría que habitaras este poema

como habitas mi vientre, que fuera para ti una casa.

Que la poesía fuera tu refugio.

Tu madre

habla todas las lenguas

con acento extranjero y sabe

que siempre hay algo de intemperie en los refugios, una fragilidad que te hará fuerte.

Enciendo para ti la casa poema.

En los inviernos que conocerás, ojalá te proteja y te caliente.
CASA POEM

\section{Aș vrea să trăiești în acest poem aşa cum trăieşti în burta mea, să fie pentru tine o casă.}

Să-ți fie poezia un refugiu.

Mama ta vorbeşte toate limbile cu accent străin şi ştie

că e mereu ceva nesigur în refugii, ceva fragil care-ți va da putere.

Aprind pentru tine casa poem. In iernile pe care le vei cunoaşte sper să te protejeze şi să te încălzească.
ALGUIEN AL OTRO LADO

Una niña muy seria,

en la antigua avenida de mi infancia, me visita en los sueños.

¿Qué has hecho de mi vida?, me pregunta.

No sé qué responderle. Sólo sé que estoy al otro lado de la calle, que la niña no logrará alcanzarme.

Algo lo impedirá:

la cautelosa sombra del silencio, o la frontera súbita del miedo.

Algún día sabré qué responderle.

Tal vez no vuelva nunca, tal vez llore.

Tal vez nos convirtamos en pasaje, y yo seré su sueño:

alguien que no recuerda su pasado, con la memoria sólo del futuro.

\section{CINEVA DE CEALALTA PARTE}

\section{O fetiță tăcută,}

în vechiul bulevard al copilăriei, îmi apare în vise.

Ce-ai făcut cu viața mea? mă întreabă.

Nu ştiu ce să răspund. Ştiu doar că acum mă aflu de cealaltă parte, că nu va reuşi să mă găsească.

Ceva o s-o împiedice: umbra prudentă a tăcerii sau brusca limită a fricii.

Într-o zi voi şti ce să-i răspund.

Poate nu se va întoarce niciodată, poate va plânge.

Sau ne vom transforma într-un pasaj, eu voi fi visul ei:

cineva care nu-şi aminteşte de trecut, şi are doar viitorul în memorie. 
Alguien que necesitará saber si ha aprendido ya a perdonarme.

EL SEGUNDO PAÍS
Cineva care va trebui să ştie dacă a învățat deja să mă ierte.

\section{Un hijo es el segundo país donde nacemos}

Luis García Montero

Busco tu mano en la noche, tu minúscula mano, tu mano de bebé, talismán mío, para escapar de oscuros pensamientos.

Del alba de los días laborables. De la aterida sombra de su ausencia.

De los pliegues nocturnos donde aguarda,

cada vez más seguro de sí mismo,

cruel en su mansedumbre, el fracaso, con su inquieto latir de animal preso.

Tú sonríes dormida. Me esperas

del lado luminoso de la noche.

Y ya no tengo miedo. Me proteges.
A DOUA ŢAR $\breve{~}$

\section{Un copil e a doua țară în care ne naştem \\ Luis García Montero \\ Îți caut mâna în noapte, mâna ta minusculă, mână de bebeluş, talismanul meu, ca să scap de întunecate gânduri.}

De zorii zilelor de lucru.

De înfrigurata umbră a absenței lor. De nocturnele colțuri unde aşteaptă, tot mai sigur de el, eşecul, cu zvîcnirea sa neliniştită, de animal captiv.

Tu surîzi în somn. Mă aştepți de partea luminoasă a nopții.

Şi nu mai îmi e frică. Tu mă aperi.

CADÁVERES LLEGARON A LA PLAYA

CADAVRELE AU AJUNS PE PLAJĂ

Cadáveres llegaron a la playa.

Todo estaba tranquilo: el mar en calma, los niños con juguetes,

los bañistas absortos en sus sueños, en la pereza azul de los veranos, en el golpe apacible de las olas, en su rumor de vagas lejanías.

Los cuerpos irrumpieron de repente: trozos de carne muerta, descompuesta en medio del sopor, de la aventura que prometía el mar.

Los rodearon todos:

los niños con juguetes, los bañistas, policías y médicos movidos por un afán inútil de hacer algo.
Cadavrele au ajuns pe plajă

Totul era calm: marea liniştită, copiii cu jucării, înotătorii duşi pe gînduri, concentrați în lenea albastră a verii, în paşnica mişcare a valurilor, în murmurul vagilor depărtări.

Corpurile au apărut dintr-odată: bucăți de carne moartă, descompusă în mijlocul toropelii, al aventurii promise de mare.

Toți i-au înconjurat: copiii cu jucării, înotătorii, polițişti şi medici îndemnați de o voință inutilă de a face ceva. 
Un niño tocó un cuerpo.

Luego empezó a llorar.

Es la primera vez que ve la muerte, dijo su madre mientras lo alejaba.

Su llanto contagió a los otros niños, pequeño coro de tragedia griega.

Negros, lustrosos como el mar, los cuerpos

sin culpa y ya sin hybris, hoy parecen

las víctimas de un turbio sacrificio.

Y es la playa un altar improvisado.

Pero, ¿quién ofició la ceremonia?
Un copil atinse un corp.

Apoi începu să plîngă.

E prima dată când vede moartea, spuse mama sa în timp ce-l îndepărta.

Plânsul său îi molipsi pe alți copii, mic cor de tragedie greacă.

Negre, lucioase ca marea, corpurile, fără vină nici hybris, par acum victimele unui tulbure sacrificiu.

Iar plaja e un altar improvizat.

Dar cine a oficiat ceremonia?
ESTACIÓN ABANDONADA

Un banco, un reloj, hierbajos. Un grafitti estridente.

Pájaros a lo lejos.

Se trata de un lugar fuera del tiempo. Ya nadie espera a nadie en ese banco, pero la espera existe en cada objeto.

El tren no se detiene, la imagen dura sólo unos segundos.

Lo suficiente para comprender que lo que nos espera a fin de cuentas es siempre una estación abandonada.

\section{STAȚIE PĂR $\breve{S I T A \breve{~}}$}

O bancă, un ceas, bălării. Un grafitti strident. Păsări în depărtare.

E un loc în afara timpului. Nimeni nu aşteaptă pe nimeni aici, dar aşteptarea există în fiecare obiect.

Trenul nu se opreşte, imaginea durează doar cîteva secunde. Suficient însă pentru a înțelege că ce ne-aşteaptă pînă la urmă este mereu o stație părăsită.

UNA FORMA DE BONDAD

\section{O FORMĂ DE BUNĂTATE}

To have been loved once by someone surely

There is a permanent good in that,

Even if we don't know all the circumstances

Or it happened too long ago to make any difference. John Ashbery

Tardaste mucho tiempo en descubrirlo, y entonces aquellos versos de Ashbery te dieron la razón.

Miras por la ventana:

un cielo blanco y duro, unos tejados sucios,
To have been loved once by someone surely

There is a permanent good in that,

Even if we don't know all the circumstances

Or it happened too long ago to make any difference.

John Ashbery

Ți-a luat mult timp să-ți dai seama, şi atunci acele versuri de Ashbery ți-au dat dreptate.

Priveşti pe fereastră:

un cer alb şi sever, acoperişuri triste, nici urmă de bunătate în peisaj. 
ni rastro de bondad en el paisaje.

La luz entra a raudales, pero es una luz fría,

deja sobre las cosas su pátina de hielo.

Ya es tarde para todo.

Estos objetos no te reconocen.

Sin embargo, la cama desolada y la mesa vacía

pueden contarte bien tal como fuiste:

aquel antiguo amor desmesurado, aquellos alimentos para el cuerpo.

La soledad no enseña casi nada, sólo a medir el tiempo,

cómo se hinchan los días de aspereza,

cuánto se tarda en fracasar.

Y la punzada de un saber ya inútil:

la poesía es confirmar la vida

y el amor, una forma de bondad.
Lumina intră din plin, dar este rece, îşi lasă peste lucruri patina înghețată.

Acum e târziu pentru tot.

Aceste obiecte nu te recunosc.

Şi totuşi, patul dezolant şi masa goală

pot povesti bine cum erai: acea dragoste veche, acele alimente pentru corp.

Singurătatea nu învață nimic, doar a măsura timpul, cum se umflu zilele de gust acru, cât mai durează până la eşec.

Şi împunsătura unei lucidităţi tardive: poezia e o confirmare a vieții

şi dragostea, o formă de bunătate.

Prin ceea ce scrie visând, Ioana Gruia propune un limbaj poetic oglindă a unor trăiri şi experiențe filtrate mereu printr-un tumult al emoțiilor, ideilor şi gîndurilor dezvăluite prin imagini. $\mathrm{Cu}$ accente realiste pregnante şi în acelaşi timp duioase, poezia Ioanei Gruia se transmite tulburător creând-se ceea ce poeta numeşte a fi „o formă de bunătate”, o apreciere pusă în lumină şi de publicista şi criticul de artă Magda Cîrneci în recenzia sa din aprilie 2020, la ediția în limba română a volumului Carusel:

Poezia pe care o scrie Ioana Gruia este caracterizată de claritate şi economie a mijloacelor, de simplitate şi delicatețe. Într-o evidentă descendență realistă, poezia aceasta nu se aseamănă cu producția poetică tânără care se scrie din 2000 încoace în România. Nu e minimalistă şi nici mizerabilistă, nu merge pe explorarea dură a agresivității şi urâtului, a sexualității exhibate şi a imundului, deşi nu refuză cu totul aceste fațete ale realității. Carusel pleacă de la micile sentimente, de la viața cotidiană, de zi cu zi, pentru a-i alchimiza poetic dulceața şi suferința, ridicându-le la o anume generalitate umană. Poezia aceasta impresionează printr-o delicatețe profundă - sau invers, printr-o profunzime delicată, care, chiar dacă nu sare în ochi, rezistă bine în timp şi are o rezonanță constantă. Pentru Ioana Gruia, poezia, ca şi iubirea, e o formă de bunătate care poate răscumpăra tot greul dificil, inexorabil, irevocabil al existenței. Poezia, crede Ioana Gruia, e o inflorescență rară şi o confirmare superioară a Vieții. (Cîrneci 2020) 


\section{Mihai Gane}

Mihai Gane (1993, Lereşti) dăruieşte un lirism ce cucereşte fulgerător sensibilitatea proprie, atât spațiului iberic, cât şi a celui din țările de limbă spaniolă din America. De la vîrsta de 9 ani în Madrid, descoperă şi învață de la profesorul Rafael Ávila García cuvintele, sintaxa, ritmul, cadența, sonoritatea şi mirajul limbii spaniole. Şi astfel, îndrăgostindu-se de o lume îndepărtată şi complet diferită de cea a copilăriei de lîngă Munții Carpați, se reconstruieşte şi îşi salvează identitatea printr-o poezie pe care o împărtăşeşte cu generozitate prin intermediul formelor de comunicare specifice timpului prezent - rețelele de socializare (Facebook, Twitter, Instagram). Circumscrisă criteriilor de clasificare a literaturii ectopice sau de «dislocare lingvistică şi culturală», creația literară a lui Mihai Gane în limba spaniolă se simte naturală, nealterată de reguli şi norme din limba maternă (,...a scrie în spaniolă înseamnă a atinge cuvintele. A face asta în română înseamnă a le zgîria”). Fără un contact direct şi constant cu literatura română, poetul ectopic se adaptează şi îşi găseşte drum prin limba de adopție, un drum «apt» şi compatibil cu propria-i personalitate şi sensibilitate. În aceeaşi linie critică, Tomás Albaladejo Mayordomo (2011:150) subliniază:

Cuestiones como la del contexto de producción y el contexto de recepción de la obra, la del código o lengua en la que la obra es escrita, la de la conexión entre autor y receptor, etc. están situadas en el ámbito del aptum y son altamente sensibles a hechos como el que el autor escriba en un lugar que no es el propio o que utilice una lengua distinta de su lengua materna.

$\mathrm{Cu}$ un limbaj simplu, direct, al vorbitorului de rînd, dar în acelaşi timp delicat, reflectînd o intuiție şi înțelegere afectivă a realității înconjurătoare, Mihai Gane cîștigă prestigiu, notorietate şi devine un poet consacrat după ce, în 2016, cel mai mare grup editorial Penguin Random House îi publică Con tal de verte volar (Doar ca să te văd zburînd) şi, în 2018, Ahora que ya bailas (Acum că dansezi deja), volume de versuri vândute în zeci de mii de exemplare în Spania, Mexic, Ecuador, Columbia, Costa Rica, Paraguay, Bolivia, El Salvador, Guatemala. Dublu licențiat în Drept şi Administrarea Afacerilor, Mihai Gane alege fără ezitare calea literaturii «vindecătoare de suflete», în 2017 fiind nominalizat la Premiul Național de Poezie din Spania. În 2019, îşi face cunoscut primul roman, Cuando seas mayor (Cînd o să te faci mare), o poveste autobiografică despre dezrădăcinare, disperare, luptă, speranță, identitate şi vis. Acela de "a readuce la viață iubirea pentru cărți”. Iar din toamna anului 2020, La piel en los labios (Pielea de pe buze), la aceeaşi faimoasă editură, este o nouă încercare poetică prin care Mihai Gane se oferă, "ne caută şi vrea să ne atingă”. 
Căutând „magia aceea dintre scriitor şi cititor”, poetul mărturiseşte că scrie despre:

...dragoste, despre despărțire şi poezie socială (despre feminism, despre imigrație). Mă inspir din trăiri, din tot ce se întâmplă în jurul meu. Deschid ochii şi am nevoie de sentimente noi. Nu prea ştiu să zic "nu", aşa că presupun că şi aventura este un factor important în scrierile mele. (Axinescu 2019)

Firesc, poezii precum 1718, Desamor a distancia (Des-dragoste la distanță), En otro cuerpo (În alt corp) sînt cîteva exemple desăvârşite:

1718

A pesar de no poder tocarte ni ver cine juntos.

A pesar de esta distancia indeseada, que me lleva a querer cogerme un vuelo cada minuto que te pienso.

A pesar de tener tus fotos para ir tirando de los días.

A pesar de que no puedo leerte todos los libros que quiero.

Aunque tenga frío en primavera, aunque me pregunten por ti

y ponga cara de echarte de menos, aunque ya no tenga tu olor impregnado en mis camisas

ni tu ropa en el suelo de mi cuarto.

A pesar de que el vino no sea para dos, aun cuando quiero que me cuentes tu vida

mientras nos perdemos por Madrid, aunque sepa la exactitud de tus lunares y me muera por descubrirte algo nuevo,

aunque quiera morderte la oreja y decirte cosas prohibidas.

A pesar de este quiero tan montaña, de este no puedo tan viento, a pesar de todo ello, 1718 kilómetros, nunca, estuvieron tan cerca.
1718

Chiar dacă nu pot să te ating nici să vedem filme împreună. În ciuda acestei distanțe nedorite, care mă împinge să vreau să urc într-un avion

în fiecare clipă cînd mă gîndesc la tine.

Chiar dacă am pozele tale şi cu ele pot să mai trec peste cîteva zile.

Chiar dacă nu pot să îți citesc toate cărțile pe care le doresc.

Deşi îmi este frig în primăvară, chiar dacă mă întreabă lumea despre tine

şi pe fața mea se aşează un dor, deşi cămăşile mele nu mai au mirosul tău,

nici hainele tale nu mai sunt pierdute pe podeaua din dormitorul meu. Chiar dacă vinul nu este pentru doi, chiar şi când vreau să-mi zici despre tine în timp ce ne pierdem prin Madrid, deși îți știu forma exactă a alunițelor şi tânjesc să-ți mai descopăr ceva nou, deşi aş vrea să îți muşc urechea şi să îți spun lucruri interzise.

Deşi există un 'vreau' cât un munte, un 'nu pot' din ce în ce mai prin vânt, în ciuda tuturor acestor lucruri, 1718 kilometri nu mi-au fost, niciodată, atât de aproape.

\section{DESAMOR A DISTANCIA}

DES-DRAGOSTE LA DISTANȚĂ
Privesc ecranul telefonului o dată la câteva minute şi nu văd nici un mesaj de-al tău. $\mathrm{Nu}$ știu ce faci


si es que estás haciendo algo.

Me gustaría leer

que tienes ganas de verme,

que me echas de menos,

que te tocas pensando en mí;

- es decir, todo aquello que yo hago, cada día -,

pero no veo ningún mensaje tuyo

y debo aceptar

que en ese silencio de palabras

es cuando se termina el amor. nici măcar nu ştiu dacă faci ceva.

Mi-ar plăcea să citesc

că îți doreşti să mă vezi,

că îți este dor de mine,

că atunci când te atingi te gândeşti la mine;

- adică lucruri pe care eu le fac în fiece zi -,

însă nu văd nici un mesaj de-al tău

şi trebuie să accept

că exact acolo în tăcerea ta

e când se termină dragostea.

\section{EN OTRO CUERPO}

\section{ÎN ALT CORP}

Ojalá encuentres en otro cuerpo

lo que yo no supe mostrarte.

Ojalá que las cosas te salgan bien, y sobre todo ojalá que te quieran como tú quieres, es decir, desordenado e intenso, ese amor de película francesa, con su drama y su llanto, pero con final feliz, al fin y al cabo.

Ojalá que tus planes se cumplan, que tengas tus hijos como los sueñas, y te mudes donde siempre has querido,

que llenes tu casa de libros y cine

y gente para no sentirte sola, que vuelvas a París

y que no me recuerdes ni un instante.

Te deseo a alguien que llegue hasta tu altura,

tanto que se sorprenda cada día

de la montaña de mujer que eres.

Que busque en ti por el placer de buscar, como aquel que sabe del tesoro pero no quiere encontrarlo.

Que no quiera cambiar ni un centímetro de ti, que ame tus errores -pero no en silencio-, y comprenda y respete tus heridas sin pretender curarlas,
Îți doresc să-ți meargă bine.

Să găseşti în alt corp

ceea ce eu nu am ştiut să îți arăt în al meu.

Îți doresc ca toate lucrurile să-ți iasă bine,

să găseşti pe cineva să te iubească aşa cum iubeşti tu, adică dezordonat şi intens, dragostea aceea de film franțuzesc, cu o dramă plină de lacrimi, dar fericită, într-un sfîrşit.

Sper să ți se îndeplinească şi planurile de-a avea copii,

să te muți în casa în care mereu ai visat

şi să o umpli cu cărți şi filme

şi lume ca să nu te simți singură vreodată,

şi să te întorci la Paris

şi să nu te gîndeşti nici o clipă la mine.

Itți doresc pe cineva care să ajungă la înălțiimea ta, adică pe un vîrf de munte la fel de mare ca libertatea.

Să caute în tine pentru plăcerea de a căuta,

ca acel care caută comoara

fără să vrea să o descopere.

Să nu aibă nici cea mai mică intenție de a schimba vreun centimetru din tine, să îți iubească erorile - dar nu în tăcere -, 
que acepte que siempre tendrás

la última palabra y que no te la quite de la boca

porque justo ahí está tu fuerza.

Te deseo que no pierdas nunca esa magia que tiene el carácter

cuando las uñas se clavan en la piel.

Ojalá que te entienda, nena.

Tú siempre me dijiste que yo no sería capaz

y tenías razón.

Pero no te diste cuenta

de que precisamente por eso te quería.

Ojalá que des con quien siempre te tenga hambre,

que te lama tanto que encuentre nuevos sabores

en su lengua,

que disfrute tu piel, tus fantasías, tu sexo,

y sepa que por encima

de los cien cuerpos que tendrás

discretamente,

también necesitas un alma

dispuesto a dejarse comer.

Te deseo, pues, el amor de tu vida,

porque no se me ocurre mejor forma de despedirme,

y que esta vez seas tú quien comprenda hasta qué punto

llegué a quererte. să înțeleagă şi să-ți respecte rănile

fără să pretindă să le vindece, să accepte că mereu o să ai un ultim cuvint pe buze şi să nu vrea să te lase fără el pentru că acolo este puterea ta.

Îți doresc să nu pierzi niciodată magia aceea

pe care o ai în caracter, semănătoare cu unghiile care se înfig în piele.

Îți doresc să te înțeleagă.

Tu mereu mi-ai spus că eu nu voi fi în stare

şi aveai dreptate.

Dar nu ți-ai dat seama

că tocmai de asta te iubeam.

Să dai de cineva căruia să îi fie mereu foame de tine,

să te guste atît de mult încât limba lui

să descopere noi gusturi, să se bucure de pielea ta, fanteziile tale, sexul tău şi să ştie că mai presus de însutite trupuri ce-ți vor sta alături discret, ai nevoie şi de un suflet dispus să fie devorat.

Îți doresc, deci, dragostea vieții tale,

o fac pentru că n-am găsit o formă mai bună

de a-mi lua la revedere

şi de data asta să înțelegi şi tu cît de mult

te-am iubit.

La piel en los labios

(Gane 2020)

\section{Alina Diaconu}

Alina Diaconu (1946, Bucureşti) este o scriitoare de renume ce trăieşte de la vîrsta de 14 ani în Buenos Aires (Argentina). Cu o largă recunoaştere în mediile socio-culturale din această țară, creează în limba spaniolă ficțiune, cronici, aforisme şi poezie, printre mentorii săi numărându-se gînditori români ce au atins eternitatea: Mircea Eliade, Emil Cioran şi Eugen Ionescu. Traducându-le operele în limba spaniolă, Alina 
Diaconu este considerată ambasadoarea spirituală a culturii române în țara tangoului. Prezență constantă cu articole de opinie în revistele (Cultura, Vigencia, Asuntos Culturales, Vuelta Sudamericana) şi ziarele principale din Argentina (Clarín, La Nación, La Prensa, Perfil, La Gaceta), Alina Diaconu publică şi literatură (romane, povestiri, poezii), multe dintre cărți circulînd în lume nu numai în limba spaniolă, dar şi traduse în română, franceză, engleză, italiană. Dintre titlurile cele mai cunoscute se remarcă: romanele La Señora (Doamna) în 1975, Buenas noches Profesor (Noapte bună, domnule Profesor) în 1978 (volum premiat cu Mențiunea de onoare a Societății Scriitorilor Argentinieni), Enamorada del muro (Îndrăgostită de zid) în 1981, Cama de ángeles (Pat de îngeri) în 1983, Los ojos azules (Ochii albaştri) în 1986, El penúltimo viaje (Penultima călătorie) în 1989 (roman distins cu premiul Meridianul de argint), Los Devorados (Devorații) în 1992, Una mujer secreta (O femeie misterioasă) în 2002, Avatar (Avatar) în 2009; volumul de nuvele din 1995 ¿Qué nos pasa, Nicolás? (Ce ni se întâmplă, Nicolae?); cărțile de poezii Intimidades del ser (Intimitățile ființei) în 2005, Poemas del silencio (Poemele tăcerii) în 2007, Aleteos (Bătăi de aripi) în 2015, Rosas del desierto (Trandafiri ai deşertului) în 2019. Voce singulară, de înaltă erudiție, Alina Diaconu se exprimă şi se destăinuie prin gînduri, idei şi reflecții cuprinse, de asemenea, în cărți de interviuri, eseuri, note şi aforisme. Astfel, în 1998 publică Preguntas con Respuestas (Întrebări cu răspunsuri - interviuri cu Emil Cioran, Eugen Ionescu, Jorge Luis Borges, Alberto Girri şi Severo Sarduy) şi Calidoscopio. Notas acerca del amor, el poder, el tiempo y otros espejimos (Caleidoscop. Note despre dragoste, putere, timp şi alte iluzii). In 2009, propune un Ensayo General (Eseu General), iar în 2016, se prezintă publicului literar cu o carte de aforisme, Relámpagos - Máximas y Mínimas (Străfulgerări - Maxime şi Minime), urmată în 2017 de Gritos y susurros - 30 años de argentinidad (Strigăte şi şoapte - 30 de ani de argentinitate), o selecție de articole publicate în presa argentiniană. Legat de opera Alinei Diaconu, demn de semnalat este volumul de critică apărut în 1993 - Utopías, ojos azules y bocas suicidas: la narrativa de Alina Diaconu (Utopii, ochi albaştri şi guri sinucigaşe: narativa Alinei Diaconu) - volum alcătuit de către profesoarele Ester Gimbernat González (Universitatea de Stat din Colorado, SUA) şi Cynthia Tompkins (Universitatea de Stat din Arizona, SUA).

Şi în cazul acestei sensibile autoare tematica scrierilor sale corespunde pe deplin cu acele conținuturi proprii literaturii ectopice, sunt teme prin care Alina Diaconu vorbeşte în limba spaniolă şi pe unde nostalgice despre îndepărtări, tăceri şi destin, iluzii, enigme şi himere, existență şi sensuri, iubire şi revisări. O tematică mereu în directă relație cu starea de spirit a celor ce o citesc, o creație prin care se destăinuie imaginația tânără, deschisă, dinamică şi entuziastă a unei «devoratoare de cărți»: 
Soy y seré una devoradora de todo tipo de libros: desde las biografías hasta los de poesía, desde los ensayos hasta los de aforismos, desde los libros de filosofías orientales hasta los de autoayuda. A estas alturas, creo que no hay reglas para escribir bien, sino para mejorar lo que ya se trae como legado, apuntalando una buena idea, algo interesante para compartir. (Diaconu 2012)

În concordanță cu un crez artistic, textele lirice propuse mai jos din volumul Poemele tăcerii (Poemas del silencio) sunt poeme dintr-un suflet în căutarea contemplării, frumuseții, stilului şi unicității:

\section{LA OTRA HISTORIA}

Toda nuestra vida se va con esta vida.

Nuestros amuletos, nuestros amores, las euforias volátiles, las hondas desesperanzas, la infancia toda con toda su polifonía.

Los manjares preferidos, los libros y los héroes y los maestros y los viajes por

la ancha geografía del mundo y los silencios,

la música sagrada, las sonrisas de las diosas, y, por supuesto, la escritura. Todo se va cuando nos vamos, Todo esto.

Lo que sobrevendrá será ¿quién sabe?

Probablemente otra historia, nunca ésta.

Como dicen los iluminados ¿será una historia de paz, de libertad y de sapiencia?... ¿Acaso, por fin, el amor eterno? Sea cual fuere, será otra historia.

$\mathrm{Y}$ a esta nueva historia la llamaremos Muerte.

\section{ACOMPAÑAMIENTO}

$$
\begin{gathered}
\text { ¿Quién dijo } \\
\text { que estamos solos? } \\
\text { ¿Y las nubes, } \\
\text { y el sol, } \\
\text { y las palomas? }
\end{gathered}
$$

¿Qué son?

¿Y los árboles, y la lluvia, y el viento?

¿Quién dijo que estamos solos?

$¿ Y$ las mariposas, y los ángeles, y los dioses, y las diosas, y el silencio colmado de presencias?

$$
\begin{gathered}
\text { ¿Quién dijo } \\
\text { que estamos solos? }
\end{gathered}
$$

\section{ACEPTACIÓN}

¿Cómo aceptarlo todo sin resistir?

¿Cómo fluir con la corriente sin usar lo que creemos es nuestra preciada voluntad? ¿Cómo dejar que las cosas sean no como nosotros las queremos?

¿Cómo sustituir terquedad por flexibilidad, imposición por aceptación, sin que eso sea renuncia? ¿Cómo existir sin esfuerzo? ¿Cómo abandonar la lucha que nos posibilita

una vana sensación de triunfo? ¿Cómo soltar

la idea de cambiarlo todo a nuestro antojo e intentar cambiarnos nosotros a nosotros mismos, 
olvidando la propuesta

de cambiar el afuera?

Acaso la respuesta

a tanto interrogante

sea entender que esas son

las causas de la ira

y que su supresión es suprimir a ese arremolinado enemigo.

\section{MAÑNANA}

$$
\begin{gathered}
\text { Entreveo mi ocaso } \\
\text { en este mundo, } \\
\text { haciendo } \\
\text { vida }
\end{gathered}
$$

contemplativa.

Podría ser

frente al mar,

o a un lago

o a un cerro nevado.

La elección estaría en Quien elige.

El Universo

sabe lo que hace,

pero también escucha

los deseos.

No tengo miedo ya, confío.

Intentaré explorar

la anteúltima instancia.

\section{JARDINES SECRETOS}

Todo es vibración de elixires, néctar de dicha, por desdicha no dicha, ya que la palabra naufraga.

\section{EL MONJE ZEN}

No se pueden hacer dos cosas al mismo tiempo. Clavada en mí estaba la búdica mirada del monje Zen.

Una cosa por vez, claro está.

No puedo tomar café y leer el diario. Ni mirar el mar mientras escucho a Shaina Noll. No se pueden hacer dos cosas al mismo tiempo.

Lo que me quería decir el monje Zen es que no debía estar tomando apuntes mientras él hablaba.

No era por él ni por su "yo" renunciado, era por mí

y una mayor claridad. Sí. No.

No se pueden hacer dos cosas al mismo tiempo, ni tres, ni cuatro. Vivimos desenfocados, fragmentados, distraídos, multifacéticos, disociados, atolondrados, queriéndolo hacer todo, sin hacer bien nada.

Poemas del silencio/ Poemele tăcerii

(Diaconu 2007) 


\section{Bibliografie}

Albaladejo Mayordomo, Tomás. (2011). "Sobre la literatura ectópica," In: Adrian Bieniec, Szilvia Lengl, Sandrine Okou, Natalia Shchyhlebska (eds.), Rem tene, iverba sequentur! Gelebte Interkulturalität. Festsschrift zum 65. Geburstag des Wissenschaftlers und Dichters Carmine/Gino Chiellino, Dresden, Thelem, pp. 141-153.

Axinescu, Ionuț. (2019). "Miguel Gane, poetul de origine romînă considerat o "senzație literară” în Spania şi în America Latină," interviu Viitorul României, https://viitorulromaniei.ro/\%202019/08/o9/miguel-gane-poetul-de-origineromana-considerat-o-senzatie-literara-in-spania-si-in-america-latina/

Cîrneci, Magda. (2020). „Ioana Gruia - poezia ca formă de bunătate”, Observator Cultural, nr. 1010, https://www.observatorcultural.ro/\%20 articol/ioana-gruiapoezia-ca-forma-de-bunatate/

Diaconu, Alina. (2007). Poemas del silencio. Buenos Aires: Lumiere.

Diaconu, Alina. (2012). "La esencia desnuda de un escritor," La Nación (Argentina). https://www.lanacion.com.ar/cultura/la-esencia-desnuda-de-un-escritornid1456623/

Firan, Florea. (2018). „Alina Diaconu”, Scrisul Românesc, 4 (176): 1-3.

Gane, Miguel. (2020). La piel en los labios. Madrid: Aguilar.

Gruia, Ioana. (2015). Soarele în fruct/El sol en la fructa (traducere din limba spaniolă de Ioana Gruia). Bucureşti: Editura Tracus Arte.

Gruia, Ioana. (2016). Carusel (traducere din limba spaniolă de Ioana Gruia). Piteşti: Editura Paralela 45. 